\title{
Building Union Power Across Borders: The Transnational Partnership Initiative of IG Metall and the UAW
}

\author{
Michael Fichter, Global Labour University, Germany
}

\begin{abstract}
This is a case study of how the transnational cooperation between two unions - IG Metall in Germany and the United Automobile Workers (UAW) in the United States - was put on a new trajectory. It is a template for the challenges unions face in adapting their nationally oriented selfinterest toward building transnational solidarity and being able to leverage global corporate power in defence of workers' interests across borders. Using the power resources approach, it highlights the unions' transnational strategy built on mobilising associational and institutional resources. Understanding their make-up and utilisation became crucial in the process as limits to institutional power without involvement and mobilisation on the ground became evident. The case study focuses on the initiation and preparation phase of a more comprehensive organisational cooperation, culminating in a formal agreement to establish a Transnational Partnership Initiative (TPI) in 2015. While no organising gains were made in this phase - indeed, only losses - it was crucial for building trust and mutual understanding, as well as for actively promoting a broadly based anchoring of the TPI in terms of policy in both unions. The case study's conclusions are generally positive on this count; yet they are preliminary as the overall project is a work-in-progress and its basis of support beyond the two unions (societal power) is still untested.
\end{abstract}

\section{KEYWORDS}

automotive industry; transnational union cooperation; solidarity; self-interest; associational power; institutional power

\section{Introduction}

In the history of the United States (US) labour movement, the United Auto Workers (UAW) has played a leading role. Its success in unionising the industry in the 1930s laid the groundwork for the substantial gains made by labour across many sectors following World War II. The UAW established itself as a powerful organisational fixture representing workers' interests at the three major US auto manufacturers - General Motors (GM), Ford and Chrysler, the so-called Big Three - as well as at their major suppliers. But since the 1980s its influence has waned, as it proved unable to extend its power base to the plants built by Japanese, Korean and German auto-makers (so-called "transplants") in the southern American states with their low wage levels and anti-union politics. 
Following his election in 2010, UAW President Bob King set his union's efforts to organise the transplants by reaching out to their home-country unions. Most encouraging was the response of IG Metall in Germany, a union of over 2.2 million members throughout the metal, woodworking and textile industries. Its institutional power, anchored in its extended collective bargaining coverage and flanked by company works council and supervisory board mandates was regarded as a "game changer" in the UAW's goal of gaining recognition at Volkswagen, Mercedes (Daimler) and BMW. Although relations had not been close for many years, and at times even antagonistic, King's initiative resonated particularly well in IG Metall's International Department. Its director saw an opportunity to build a stronger relationship with the UAW and for IG Metall to take a more active role in supporting UAW recognition efforts at the new Volkswagen plant in Chattanooga, Tennessee, and at the Mercedes plant in Alabama. Within IG Metall, this engagement could be framed in terms of contributing to the membership-driven policy orientation of enhancing associational power (Wetzel, 2013). As such, support of the UAW's self-interest could be articulated in terms of the IG Metall's own self-interest. Although not yet a coherently argued new approach to transnational partnerships, both unions were laying the groundwork for what eventually culminated in a greater organisational commitment to increasing transnational cooperation following the UAW's crucial organising defeat at Volkswagen. In the spring and summer of 2015, the governing bodies of the UAW and IG Metall established a Transnational Partnership Initiative (TPI). The purpose of the TPI is to "collaborate to improve wages and working conditions for employees at German-owned auto manufacturers and suppliers in the U.S. South" and to "expand on the principle of "codetermination' between management and employees by establishing German-style works councils or similar bodies to promote employee representation" (UAW, 2015b).

This case study deals with the laying of the groundwork that led to the establishment of the TPI, which is currently still a "work in progress". In time, the steps taken in this phase will put the transnational cooperation of the two unions on a new trajectory and provide an opportunity for exploring challenges of building a viable organisational basis for transnational union cooperation. Academic interest in labour's leverage in global value chains has been growing (for example: Newsome, Bair and Rainnie, 2015; Niforou, 2015), and there is an increasingly large body of case studies on transnational solidarity to draw on (among the more recent: Fairbrother, Hennebert and Lévesque, 2013; McCallum, 2013; Fichter and McCallum, 2015). But with few notable exceptions (Lévesque and Murray, 2010a; Brookes, 2013, 2015, 2017), the power resource approach as it was used in the project on Trades Unions in Transformation (initiated by the Friedrich Ebert Stiftung [FES], 2017) is largely absent from the analysis of trade union transnationalism (see Introduction to this Special Issue).

In particular, this case sheds light on the many operational challenges of cross-border cooperation, especially when it is meant to be linked to policy and decision-making at the local and national levels within each union. Using the power resources framework provides insights into these challenges by highlighting the relational nature of power along with the interdependency of structural, associational, institutional and societal power resources. The question of strategically mobilising power resources will be addressed using a catalogue of capabilities introduced by Lévesque and Murray (2010b). 
The case study is based on public and internal union documents, interviews, ${ }^{1}$ and my personal experiences as a consultant and participant observer. It begins with a general introduction to the national and transnational context of the two unions' responses to the globalisation of the auto industry. This is followed by a presentation of the UAW's plan to organise the German transplants. The third section covers the implementation of the plan up to the stunning organising defeat at the Volkswagen plant in Chattanooga in February 2014. Sections four and five then focus on the responses of the two unions to this defeat and the development of a more comprehensive commitment to transnational cooperation. The final section uses the power resources approach to provide a critical reflection and analysis of the results and successes of this case, remembering at the same time that it represents only one phase - albeit a highly important one - in a more comprehensive "work in progress". While cross-border cooperation and solidarity were given an organisational and conceptual boost, its effectiveness, and sustainability, will depend heavily on the extent to which the active involvement of members in both unions can be developed.

\section{UAW and IG Metall: Background and Context}

Since the 1980s both the UAW and IG Metall had been grappling with the challenges of globalisation and automation. Both faced outsourcing, offshoring and the spread of temporary agency work, but there were important differences in context and policy. Up to the 1980s, UAW's membership had grown steadily, reaching a peak of over 1.5 million members in 1979 . However, by 2000, the UAW had lost 56 per cent of its membership due to automation, the offshoring of jobs in the auto industry and the increase in non-union plants at suppliers and foreign manufacturers. At the time of King's election, UAW membership was below 400 000. King saw the future of the union endangered if this trend were to continue. Speaking to a union conference in January 2011, King told the delegates, "If we don't organize these transnationals, I don't think there's a long-term future for the UAW, I really don't" (quoted in Thomas, 2011: n.p.).

Since the 1980s, Japanese, Korean and German manufacturers have been opening new production sites (and drawing in suppliers) in the US South, ${ }^{2}$ where wages are significantly lower and unions are hamstrung by legal restrictions (the so-called "right-to-work laws") ${ }^{3}$ and under siege by employers' aggressive anti-unionism. Today, foreign transplants employ about 75000 workers and account for more than half of US auto production. None of them has a recognised union or a collective agreement. The situation at auto suppliers, where three out of four American auto workers are employed (Ruckelshaus and Leberstein, 2014), is not much better (Bronfenbrenner and Hickey, 2004; Aschoff, 2012: 137; Ruckelshaus and Leberstein, 2014). While the UAW maintained its

\footnotetext{
${ }_{1}^{1}$ The interviews were conducted under the condition that they would be used as background information and not be cited.

2 The auto industry grew in Kentucky, Tennessee, South Carolina, Georgia, Alabama and Mississippi (Rubinstein, 2000; Rubinstein and Kochan, 2001).

${ }^{3}$ Right-to-work laws exist in over half of the 50 US states. While federal law requires legally recognised trade unions to represent and bargain on behalf of all employees in a bargaining unit (plant or company), whether they are union members or not, right-to-work laws at the state level allow non-members to avoid paying any fees in support of union representation activities.
} 
collective bargaining arrangements with the Big Three, it has been unable to extend this institutional power to cover the transplants. Prior to King's presidency, the UAW lost organising drives at BMW (Spartanburg, Georgia), Honda (Marysville, Ohio), Nissan (Smyrna, Tennessee) and Mercedes (Vance, Alabama). None of these was marked by substantial involvement of international unions or unions from the transplant's home country. Nor did institutional contacts gained through supervisory board positions at Opel in Germany, or at DaimlerChrysler in the United States lead to organisationally anchored transnational policies. ${ }^{4}$ As more than one high-ranking UAW staff member noted, the 1980s and 1990s were a time when the UAW's arrogance regarding its supposed associational and institutional power at home isolated it transnationally. Internationalism was promoted, but it was the domestically driven policies that counted (Logue, 1980).

During the 1980s, IG Metall was also confronted with a number of challenges - automation, work reorganisation, outsourcing and offshoring. But market conditions were different in Europe and job loss was in no way comparable to the United States. IG Metall had come out of a series of conflicts in the 1970s in a much stronger position than the UAW to cope with these changes. Organisationally, it was holding its own. During the 1980s, membership hovered at around 2.6 million, with some 40 per cent of union members employed in the auto industry. And institutionally, the West German setting of labour relations, with its industrial unions and industry-wide contract agreements, not only provided a more comprehensive and stable environment for negotiating change but worked as a deterrent to foreign automakers (Turner, 1991). IG Metall developed extensive policy programmes for "rationalisation protection" and "group work", and despite bitter employer resistance successfully conducted a long strike and mobilised public support for cutting weekly hours from 40 down to 35 (Silvia, 2013: 122).

Organisational challenges unleashed by the demise of the Soviet bloc and the subsequent unification process largely absorbed the German unions during the decade of the 1990s (Fichter, 1997). The formerly stable world of the "German model" of labour relations was being undermined as German industry took advantage of the new investment opportunities and the lucrative low-wage labour markets in eastern Germany and in the countries of Central and Eastern Europe to expand and relocate. Often the mere threat of relocation sufficed to force through more flexibility and optouts in union contracts. While union institutional power proved to be unable to prevent the government from deregulating the labour market and promoting temporary agency work, IG Metall was still able to protect its core positions, even in the wake of the global financial crisis of 20072008, which disrupted auto production in Germany and threatened to leave tens of thousands of auto workers unemployed. Indeed, it seems that the union was even able to strengthen its base (Silva, 2013: 170ff).

At the end of the 1990s, the merger between Daimler AG and the Chrysler Corporation ostensibly offered an opportunity for the two unions to close ranks, but the result was greater acrimony. As the corporate merger increasingly grew into an economic fiasco, neither the UAW nor IG Metall found common ground for cooperation.

Nevertheless, with the three major German car manufacturers (BMW, Mercedes and Volkswagen) dedicated to having production facilities in the United States, and major US auto

${ }^{4}$ UAW representation on the board of DaimlerChrysler was, however, used to secure a card check/neutrality agreement at Daimler Trucks North America that led to the recognition of the UAW at one of the largest plants in North Carolina. 
suppliers (Delphi, Visteon and VDO) expanding operations in Germany, IG Metall felt that it was necessary to work with the UAW. By the end of 2008, with the union under new leadership, IG Metall's International Department was successful in reopening lines of communication with the UAW.

\section{UAW: New Leadership and a Bold Plan for the Twenty-first Century}

Bob King framed the task of organising the foreign auto makers (the transplants) in the context of a new UAW. The "UAW of the twenty-first century must be fundamentally and radically different from the UAW of the twentieth century", King (2010: n.p.) stated. In order to "address the challenges of rebuilding a global middle class", the UAW had to recognise that "flexibility, innovation, lean manufacturing and continuous cost improvement are paramount in the global marketplace". The lesson of cooperation with the Big Three in overcoming the crisis of 2008-2009 was so positive, he believed, that the twenty-first century UAW "no longer views these managements as our adversaries or enemies, but as partners in innovation and quality. Our new relationships with these employers are built upon a foundation of respect, shared goals, and a common mission". King also expressly welcomed the foreign auto makers...

...as partners and colleagues in the industry. We appreciate the fact that you are providing good jobs here. We admire many of your good policies and practices, including the focus on continuous improvement, quality and productivity. The transplants are an important and essential part of preserving, maintaining and growing our manufacturing base in this country (King, 2010: n.p.).

But at the same time, too many employers had chosen to make the United States "union free", counteracting workers' rights to free speech as guaranteed by the US Constitution. And for that reason, the UAW was ready to take action to defend "the principle of a fair secret-ballot election in which workers can decide freely whether or not to join the union” (King, 2010; see also Grossfield, 2011).

Shortly thereafter, the UAW published its Principles for Fair Union Elections, which sought to create a level playing field in the increasingly acrimonious process of union recognition resulting from employer "union-busting" attacks (Logan, 2006). In that document, the UAW (2011) called on employers to endorse eleven principles such as "no coercion", "equal access to the electorate" and "no disparaging of the other party" in order for the climate of fear to be eliminated and to allow for "free, democratic elections".

For King, "rebranding" the UAW in terms of partnership and appeals to the employers to refrain from "union busting" needed to be complemented with union power. Thus he also spoke of the need to mobilise "all 1 million active and retired members in the organizing push" (quoted in Thomas, 2011). Equally important, the UAW needed partners. To organise the foreign transplants in the US South, the UAW was ready to make a concerted effort to reach out to the home-country unions of those foreign corporations and to enlist their support in this endeavour. King took the unconventional step of telling an international audience of union representatives from the auto 
industry that the UAW needed help (Industriall, 2010: n.p.). ${ }^{5}$ And it was IG Metall that became his primary choice, because of its high membership density in the auto industry coupled with the institutional power of supervisory board members and employee representative bodies (works councils) at German auto manufacturers and suppliers. King had worked with IG Metall representatives as head of the UAW Ford department, on the supervisory board of Opel in Germany, and in global auto committees at the International Metalworkers' Federation. In addition, King reasoned that German auto manufacturers - BMW, Daimler/Mercedes and Volkswagen were more open to building cooperative relationships with the UAW because they had negotiated and signed global framework agreements with the unions whereas the Japanese and Korean brands had not (Fichter, Stevis and Helfen, 2012). To King, these agreements signalled that top management in the German auto industry acknowledged responsibility for upholding international labour standards in their global operations, whereas their US managers were unwilling to back off from their anti-union stance. He saw these agreements as a means for IG Metall to force German management to treat unions in the United States as they were treated in Germany - with respect for labour rights (IG Metall, 2011). Presented as it was in a cooperative spirit, this was an argument that could resonate in IG Metall: poor working conditions and low wages in other countries could foster whipsawing and be used by the auto manufacturers as a bargaining chip in contract negotiations with the IG Metall.

\section{From Plan to Action: Testing Stepped-up Cooperation}

To back up his initiative, King travelled to Germany to meet with IG Metall leaders and works councillors and to introduce himself to German management. This initial outreach was generally regarded as an "ice breaker in terms of union cooperation", and the two unions set about planning joint activities in support of organising the German transplants. First, the UAW founded a new Global Labor Institute in early 2011 to add a global dimension to its organising drives at foreign transplants. Then the UAW took a select group of organisers to Germany to participate in a five-day joint seminar with IG Metall staff representing different departments, along with employee representatives from VW, Daimler and BMW. It was an important step in sharing experiences and building personal relationships toward working together across distinctly different settings of labour relations. In particular, the Germans sought a better understanding of "organising" and why it was so difficult to unionise the foreign transplants in the United States. For the UAW participants it was the role and influence of works councils that was high on the agenda. Some participants were even keen to talk about how to establish works councils in the United States. As a follow-up, UAW participants then travelled to either Volkswagen or Daimler headquarters in Germany to meet with works councillors and discuss plans for cooperation in their organising drives. This kind of dialogue was new, coming not in the midst of employer attacks but rather occurring proactively, in preparation for an organising drive. As such, it was a step toward developing more organisational continuity and a common understanding of what each participant could do, what their responsibilities were, and what

\footnotetext{
${ }^{5}$ King made these remarks at an International Metalworkers Federation Automotive Working Group meeting in Detroit on 8-9 November 2010. The report of the meeting does not say that King literally called for help, but participants at the meeting confirmed this to me.
} 
each side could expect from the other.

The outcome of these stepped-up contacts differed from one German auto maker to another, reflecting different constellations of interests and priorities. At BMW the works-council leadership was not ready to invest the needed resources. The works council at Daimler was basically ready to support a UAW organising drive at the Mercedes plant in Alabama, but it wanted assurances from the UAW regarding its resolve and was cautious about the resources it could commit. And it wanted IG Metall headquarters staff to recognise that the extent of cooperation with the UAW would be its decision alone. As a first step in support, it referenced Daimler's global framework agreement (DaimlerChrysler et al., 2002), calling on management to issue a statement that the company would remain neutral during a union organising drive, respecting the legal rights of workers to decide on union representation without interference from management. When top management in Germany ignored the request and local Mercedes management in Alabama denied access to the workplace for the UAW and works council representatives from Germany, UAW and the Daimler works council decided to move forward anyway on a joint programme of regular visits by German works councillors to the UAW organising committee at the US plant, participation by US worker representatives in the meetings of the Daimler World Employee Council, and exchanges between UAW representatives at the Daimler Truck plants in North Carolina and workers from the nonunion Mercedes plant in Alabama. During 2012, Daimler works councillors held week-long training sessions for Mercedes workers, did joint house-calls with their UAW colleagues, and published a UAW-IG Metall newsletter. But despite intense cooperation and a successful recognition campaign at a nearby supplier to Mercedes during this time, the organising drive was not gaining the support necessary to overcome the 50 per cent plus one hurdle needed for recognition. Workers were open to the idea of establishing a works council once the union had been recognised, but they feared that Mercedes management was not really neutral and that there would be reprisals if they openly supported the union.

The real priority for the UAW, though, was the organising drive at Volkswagen. Given VW's record on international labour rights and the strength of IG Metall and the works council in Germany, choosing to begin organising the South at VW seemed to be the most promising approach. Volkswagen boasted about its global agreements that recognised and secured the rights of its employees around the world (Volkswagen et al., 2002, 2009). In order to augment the organising work at the plant, King and his Director of Region 8 (the US South) began travelling to Germany regularly, having opened an on-going dialogue with the VW works council and the corporation's human resources department. The UAW regarded this direct line of communication with VW headquarters as so important to its organising drive that it accepted the refusal of the VW participants to make these talks trilateral by including staff from IG Metall's International Department.

Talks continued for over a year in Germany, and the UAW closed in on gaining enough supporter signatures to claim recognition. But the plan ran into problems that ultimately cost the UAW a victory. For one, at the Chattanooga plant, VW's "worker and union friendly" image was being undermined by an anti-union climate pushed by local management. Workers who openly supported union representation reported being harassed and disciplined by supervisors. The UAW passed on those reports to the works council and VW management in Germany, but it took over a year before the responsible managers in Chattanooga were finally removed. Their replacements ended the most blatant anti-union practices, but they could not stem the anti-union talk of line 
supervisors and their harassment of union supporters on the shop floor.

As the UAW-VW talks continued in Germany, another complication arose. The chairman of the VW works council made it clear that having a union at the plant was of less importance to him and in his mind, to the company - even though, as he eventually came to realise, under US law there would be no works council without union recognition first. His main concern was to be able to set up an "in-plant body of workers' representatives" - that is, a works council. The UAW was not at all opposed to having a works council; in fact, it had already started to look into the feasibility of transforming its own joint committee programmes negotiated in contracts with the Big Three into a structure along the lines of the German model. But it had to get recognition before bargaining over such a works council could even begin. And for that, the UAW needed the full support of the VW works council in Germany.

Thirdly, the UAW had been led to believe that VW would accede to union recognition if the UAW could certify that it had support cards signed by over 50 per cent of the workers. However, when the UAW produced those cards in the autumn of 2013, VW management balked, demanding that a secret-ballot election be held instead. This was a setback for the UAW and a sign that there might be more anti-union trouble ahead. It agreed to an official election in February 2014, feeling confident of winning because it had the backing of IG Metall, solid support at the workplace, and an agreement that VW was not going to run a typical union-busting campaign. What was not part of the strategy - and this was the fourth problem - was that the UAW had acceded to VW's demands that it refrain from community-support activities and not call on workers in their homes. So while the UAW maintained a publicly low profile, outside the plant a well-funded coalition of anti-union groups with local and national business support was waging a massive campaign against the union. On top of that, leading Tennessee politicians, including the governor and a US senator, weighed in against the UAW with threats of dire economic consequences should the UAW win. And there was organised resistance even inside the plant - though not officially sanctioned by VW - which spread dissention and uncertainty. As a result, what seemed like an almost certain win turned into a narrow, yet painful loss following the election on 14 February 2014 (Elk, 2014; Brooks, 2016; Silvia, 2017).

\section{Transnational Cooperation: From Support to a New Kind of Partnership}

The loss was a shock to both the UAW and IG Metall, a shock that triggered anger and then calls for a review of what had gone wrong and proposals for what to do next. Organising drives focused on the German auto makers had been stopped, and the approach to transnational cooperation - in which the UAW dealt directly with the works council at Daimler and with the works council and management at VW - had proven to be inadequate. IG Metall headquarters staff had built a strong relationship with the key UAW officials involved, but the refusal of the works councils (and VW management) to include IG Metall staff on an equal basis - and thus make the cooperation a transnational union project - had inhibited putting the project on a broader organisational basis.

Within weeks the two unions began to outline the elements of a more comprehensive plan of transnational cooperation that would build on maintaining existing bases of engagement on the ground. Firstly, the UAW was not ready to give up on union recognition and a contract at Volkswagen. That remained its top priority. That meant being willing to continue a dialogue with VW management and the works council in Germany, as well as maintaining a presence at the VW 
plant. It was decided to establish a new union local at the Chattanooga plant, a step the UAW normally took only after gaining recognition at a workplace. This was supported by IG Metall, and both unions agreed that a UAW local should also be established at the Mercedes plant in Alabama. Secondly, the focus of cooperation was broadened to include German auto suppliers located in the US South. For the UAW, this realignment linked well to its renewed focus on organising US auto suppliers. German auto suppliers employed well over 50000 workers and had a much lower rate of union density (13 per cent) than auto suppliers overall (20 per cent) (Liebman, 2016: 146). For IG Metall's International Department this value-chain approach presented an opportunity to involve other union departments dealing with the auto industry in Germany and Europe. Indeed, while cooperation between the two unions had improved notably since 2011, the magnitude of opposition to unionisation that had surfaced in Chattanooga was a clear sign that continuing with the usual form of transnational cooperation, run by a small group of experts from union headquarters, was not a recipe for success. The work of these experts had to be put on a broader organisational basis to enable other headquarter departments and union locals on the ground to have a stake in the project. And thirdly, a plan was drafted for establishing an organisational centre in the United States staffed from Germany for information exchange and policy development. The centre would be a focal point of multi-level interaction both within and between the two unions, for example by involving company-level union representatives from both unions and works councillors in Germany.

\section{Putting Partnership into Action}

It was the backing of the leadership in both unions that was decisive in making the drafting of a new plan based on increased activity and the investment of considerably more resources possible. Both unions came under new leadership after the election at Volkswagen: In the UAW, Bob King's successor, Dennis Williams, kept tabs on the progress being made and voiced his support. In IG Metall, the election loss at VW had convinced Detlef Wetzel, who had succeeded Berthold Huber as chairman in 2013, that IG Metall needed to "transnationalise" its organising policy. In July 2014 the UAW announced the founding of Local 42 at the VW plant in Chattanooga; three months later Local 112 was founded at the Mercedes plant in Vance, Alabama. By the end of 2014 the UAW-IG Metall working group had finalised a formal agreement that was ratified by the executive boards of both unions in the spring of 2015. It took several more months of planning and legal work before the UAW and IG Metall officially opened the Transnational Labor Institute (TLI) in Spring Hill, Tennessee, on 19 November 2015. In its member magazine, the UAW explained that the TLI had two main goals to fulfil:

- [The UAW and IG Metall would collaborate] to improve wages and working conditions for employees at German-owned auto manufacturers and suppliers in the US South.

- Expand on the principle of 'co-determination' between management and employees by establishing German-style works councils or similar bodies to promote employee representation (UAW, 2015a: n.p.).

IG Metall concurred, adding that the TLI would also seek to "intensify the exchange of information between German and US trade unions. It will develop educational programs for trade unionists and the interested public in order to increase mutual understanding regarding questions of trade union 
policy and codetermination at the workplace” (IG Metall, 2015: n.p.).

The founding of the TLI ushered in a new phase in the relationship between the two unions. Both were under new leadership ready to continue their support for the project. Building bilateral transnational cooperation by moving from sporadic to committed and institutionalised interaction over an extended period of time may seem to be a logical and straightforward exercise, but in the context of international trade unionism it is rather unique - in particular coming in the wake of the ominous election loss at VW. As with the campaign partnership between the German service union ver.di and the Communications Workers of America (CWA) to gain union recognition at the US telecommunications company T-Mobile (owned by Deutsche Telekom), the TLI was intentionally built on a partnership between only two unions. As a first step in a new phase of a transnational relationship, both unions argued that it was necessary to keep the partnership focused, in order to develop functional working arrangements and to avoid rivalries that a multi-organisational structure could induce. In its goals and organisational structure the TLI moves beyond the coordinating unit serving the ver.di-CWA partnership. In fact, as part of a larger transnational project with a second pilot operation in Hungary, ${ }^{6}$ the TLI is IG Metall's bridge to the UAW and its organising drives in the US auto industry. By any measure, including the level of personnel and material resources dedicated to this project in the United States, IG Metall has committed to breaking new ground in its transnational policy. For the UAW, the project is part of a broader commitment to organising the auto industry in the US South - a make-or-break situation for salvaging the associational power of the union.

As was stated at the beginning of this case study, the question of success in this phase of activities can only be addressed in terms of the organisational accomplishment of establishing a transnational partnership and not in terms of the partnership's organising goals. The goal of organising the foreign transplants, initially postulated by UAW president Bob King and later extended to include auto suppliers, was not achieved in this phase. But that failure - above all signalled by the lost vote at Volkswagen - put the quest for a robust structure of transnational cooperation on a new and more anchored footing. Considering the difficulties of the task and the extent of employer resistance, this move was necessary and represented a new commitment.

\section{Power Resources, Capabilities and the Lessons Learned}

In this section I will use the theoretical framework of our project to address the questions of what factors in the development of this UAW-IG Metall partnership led to the successful creation of the TPI and what lessons were learned in terms of what power resources came into play and which capabilities were needed to make those resources available and usable. Of primary and virtually exclusive importance for both unions in this case study was their focus on using and strengthening their associational and institutional power. When Bob King assumed the presidency of the UAW, the union's associational and institutional power, on which it had primarily relied, had been waning for nearly three decades. Not only did the UAW seem to be in an irreversible membership decline but, due to the foreign transplants' growing share of auto production and the UAW's inability to organise them and their suppliers, the union's collective bargaining coverage - a key part of its institutional

\footnotetext{
${ }^{6}$ See https://www.tpi-gyor.eu/?lang=de.
} 
power - was diminishing. The UAW's contracts with the US auto makers and major US auto suppliers no longer set standards for the auto industry as a whole, but only for less than half of it. Organising the transplants was the chosen strategy for membership growth and for establishing an organisational foothold in the US South (associational power). If successful, the UAW stood to gain in bargaining strength as well by extending its contract coverage (institutional power). While the UAW was successfully recruiting new members and building an organisational basis on the ground at Volkswagen (and to a lesser extent at Mercedes), it was counting on the institutional power of IG Metall and its works councillors to achieve the level playing field (management neutrality) it sought to have a chance at winning. From its organising drives the UAW concluded that the workers in the plants did not favour testing their structural power as a strategic option; and using societal power (that is, alliances) to mobilise pressure on Mercedes and Volkswagen from outside the workplace seemed unachievable at Mercedes and was forfeited at Volkswagen due to the conditions of dialogue imposed by management. Seeing no added value, both the UAW and IG Metall consciously excluded other US unions and the global union federation IndustriALL, of which both the UAW and IG Metall are important members, from their joint project.

For Bob King and his leadership team it was not difficult to frame the revitalisation of the UAW in terms of organising the transplants by emphasising dialogue and cooperation built on the "UAW of the twenty-first century" policy. While the UAW had had cooperative, or "joint" programmes since the 1980s, King fashioned this as the centrepiece of organising. By prioritising it, King acknowledged the union's waning associational power and lack of structural power. And as the UAW's new calling card, cooperation aroused interest in IG Metall, opening the way for a process of intermediating differing, yet not conflicting, (self-)interests between the two unions. The UAW was able to diffuse criticisms based on the past and offer a way forward to the IG Metall staff members and works councillors who were concerned about strengthening transnational union cooperation.

The core idea for developing transnational cooperation between the UAW and IG Metall was to augment the organising drives of the UAW through the institutional power of IG Metall, initially with regard to the corporate headquarters of Daimler/Mercedes and Volkswagen. At both companies, its members were in complete control of the legally mandated works councils and they held influential positions on the corporate supervisory boards. Working conditions and wages at both corporations were governed by collective agreements (including global framework agreements) with IG Metall. The equation seemed straightforward: IG Metall (union and works council representatives) would make it clear to corporate management that it was in full support of the UAW's quest for recognition and that corporate management had a responsibility to ensure that local management would refrain from employing union-busting tactics and even agree to neutrality. But as events unfolded up to the February 2014 election at VW Chattanooga, it became evident that, in practice, this equation was flawed. First of all, the assumption that this institutional power, the result of local and national struggles, could be invoked equally well transnationally, was faulty. Transnational cooperation as a proactive and strategic policy had to be learned and integrated into the agendas of IG Metall's company employee representatives. Moreover, such a strategy would have to recognise and develop means to contend with the structural, institutional and societal power of US management and politicians. ${ }^{7}$ Secondly, this power was not consolidated in the union but divided across organisational units and institutional bodies, with personal rivalries contributing added

${ }^{7}$ See for example statements of former South Carolina governor Nikki Haley (Capizola, 2014: n.p.). 
uncertainty. Employee representatives at each company were jealous of their institutional power, cautious of using it transnationally, and not ready to experiment with exercising it jointly - with each other or with IG Metall. Each wanted to determine the extent and progress of their relationship with the UAW independently.

At Daimler and Volkswagen, management claimed that, in practice, local management was adhering to corporate policy. At Daimler, the response of the works council was to shift its focus, using its institutional power more effectively to support the UAW directly in its membership drive (and later in the founding of Local 112). The VW works council initially accepted management's claim, and only in time, when the labour rights violations in Chattanooga could no longer be ignored, did it actually pressure management to intervene. That helped, but beyond that, IG Metall's institutional power at VW headquarters was never really mobilised as a challenge to the power resources of anti-union forces in Tennessee. VW management readily jettisoned union recognition in exchange for enormous tax breaks and subsidies offered by politicians (institutional power) and backed down at their insistence from a card-check agreement with the UAW. When the UAW agreed to an election, the combined institutional and societal power of the politicians and anti-union business forces then overwhelmed the nascent associational power the UAW had built within the plant.

That defeat triggered a joint process of reframing strategy and strengthening cooperation organisationally, while retaining the basic focus on enhancing associational and institutional power. While building union locals at VW and Mercedes, although with no immediate prospect of union recognition at either plant, the scope was widened and priority given to organising German auto suppliers in the US South. This required investing considerable resources, but it would be unlikely to draw the kind of anti-union activity mounted against the UAW in Chattanooga. The UAW leadership declared its readiness to bring in organising and research resources from other departments to work with the union's transnational department, anchoring the project more strongly in the union.

IG Metall's international affairs staff argued strongly in favour of this shift in focus and for a greater and more comprehensive organisational commitment on the part of the union. Their proposals for a more effective use of the union's associational and institutional power centred on transforming the project into a jointly owned UAW-IG Metall union partnership by strengthening the inter-union linkage through the TLI, mustering the support of other union departments dealing with the auto industry and building understanding of the transnational agenda among company-level union representatives and works councillors. To win over union leadership and justify the needed increase in resources, they pointed out that the partnership with the UAW was the logical and necessary transnational extension of IG Metall's policy emphasis on "organising" and targeting "union-free zones" in Germany (Wetzel, 2013). IG Metall chairman Detlef Wetzel was an outspoken advocate of this policy, and the international affairs staff built their case for transnational cooperation on the same premise. They emphasised that international solidarity, to which IG Metall was unequivocally committed, was founded on self-interest. Using the idea of "vicious cycles and virtuous circles" (see Figure 1), it was in the self-interest of IG Metall to support union organising efforts in other countries. For the International Department, and eventually the union leadership, being better, not cheaper in Germany was a strength that in a globalised world was of limited value, ending at the national borders. Even if IG Metall maintained a high level of membership density in Germany, it was dealing with corporations operating with value chains around the globe and capable of organising production wherever it was most conducive to profit-making. With their technology, 
these corporations had the capacity and the incentive to be able to produce better wherever cheaper, in most cases avoiding unions. And as long as there were union-free zones around the world, the nationally bounded associational and institutional power of IG Metall would always be under potential threat. The union had to begin finding approaches to changing this situation. And working together with the UAW - a first step in this direction - seemed to offer a plausible way of testing the viability and conditions of such an approach.
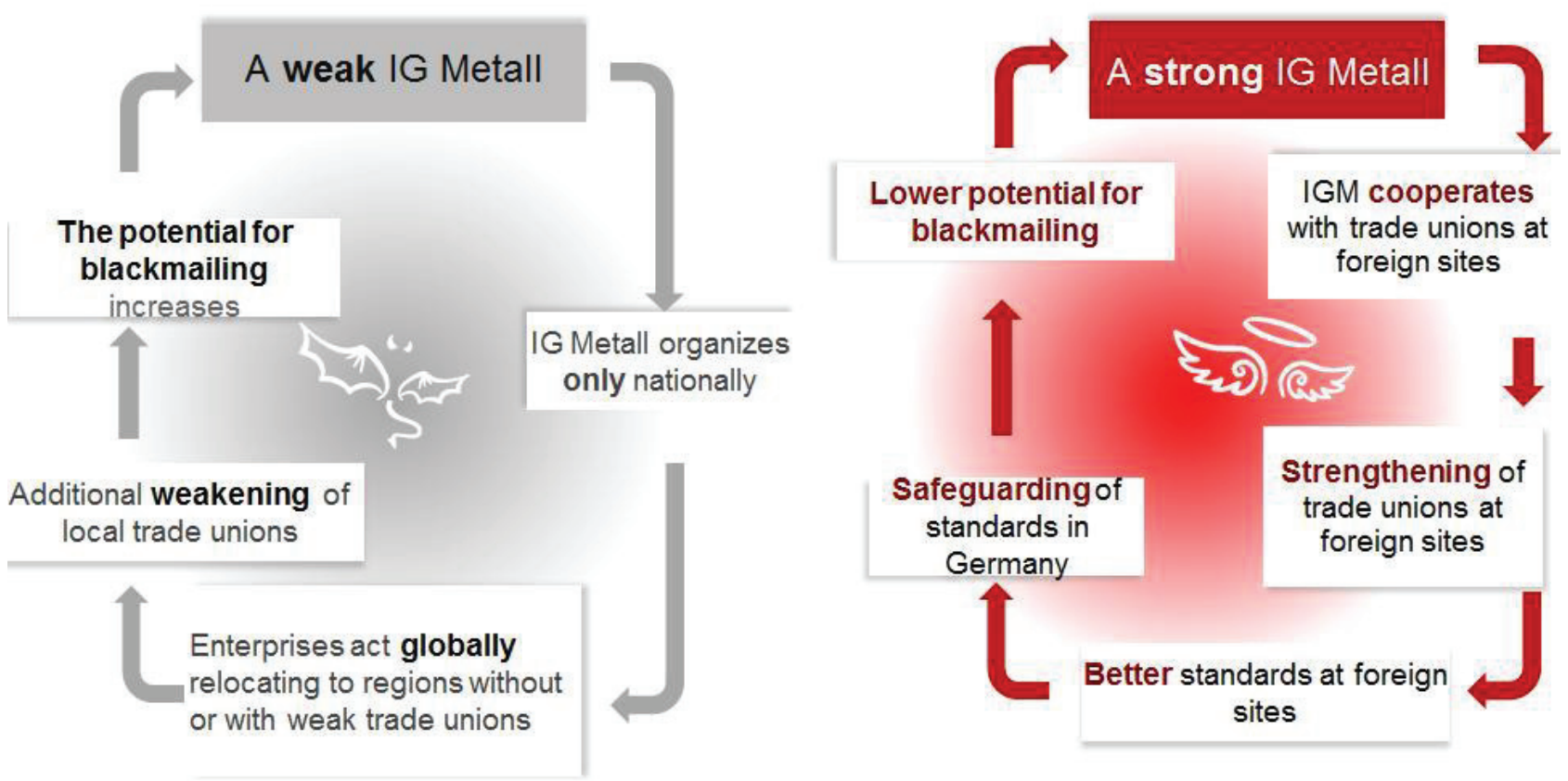

Source: Fichter and Mund (2015: 213) (author's translation).

Figure 1: Vicious cycles and virtuous circles of unionism in a globalised economy

As finally constructed, the TPI as a commitment to a middle-range pilot project of transnational cooperation was both a result of lessons learned from the past and a step toward seeking to learn for the future. In the past, transnational interaction had consisted of formalised meetings of leaders, conferences of experts, and crisis management - none of which had proven especially conducive to strengthening ties and enhancing union strength. In this sense, embarking on a new trajectory of transnational cooperation was an expression of organisational learning and organisational flexibility. While its structuring as an on-going commitment and its embeddedness as a recognised element of UAW and IG Metall policy grew out of an understanding of past failures, its sustainability as a "learning factory" for the future - critical to associational power (Greven, 2016) - is yet to be determined. Moreover, there are important questions in this "work in progress" that need to be raised as the implementation phase progresses.

One of these concerns structural power and societal power, as well as their relationship to associational power. When Bob King became president of the UAW, the union's associational and institutional 
power had diminished considerably. It was a weakened UAW that set out under its new president to regenerate its associational power. For the UAW leadership, that regeneration could only be accomplished by an offer of "peace and cooperation" based on institutional power. Although King had threatened in his election speech to "pound" Toyota if it refused the UAW's offer and to mobilise all one million UAW members and supporters, no preparations were made to give credence to such threatened action. Indeed, the course of developments at the VW plant in Chattanooga illustrate quite well that worker/member mobilisation was not part of the plan.

Although such a mobilising campaign would have had an impact, it would be speculative to claim that it could have gotten off the ground. A number of endogenous and exogenous factors make it seem unlikely, or at least extremely difficult - for example, the deeply rooted focus of union leadership on cooperation with management on the one hand, and the unregulated and heterogeneous nature of the vast US labour market on the other. Developing conflict potential and direct participation of workers on the ground to complement the superstructure of partnership has not been an essential part of the plan but, as Mark Anner (2011: 71) has concluded from his research on several transnational campaigns in Latin America, "transnationalism, without mobilization on the ground, would be unable to articulate sustainable demands at the factory level".

With regard to associational and societal power, the framing, intermediating and articulating of the strategy and its goals stayed enclosed within the organisational hierarchies of the UAW and IG Metall. And in the cases of Volkswagen and Mercedes, the opportunity to reach out to prospective labour-friendly supporters in the area was rejected in order not to pressure those corporate managers at Volkswagen and Mercedes with whom the UAW wished to negotiate and from whom they expected recognition. That left the partnership vulnerable to the whims of those corporate managers and the massive attacks of anti-union business interests. Furthermore, it raised questions about a strategy of relying on the institutional power of IG Metall. That power is not readily exercised beyond its bounded existence within the national/corporate setting. In theory, it looks impressive, but as experiences from recent organising drives at German auto supply plants in the United States show, mobilising such institutional power towards building successful transnational cooperation is a time-consuming, complex and multi-level process in which a successful outcome is almost always uncertain.

The transnational partnership is now operational and moving forward, and so the relevance of such questions and reflections is growing and coming under renewed consideration. The TPI is a work in progress, the full evaluation of which is not yet possible. But only after a substantial period of implementation will its relative importance as a contribution to growing transnational associational and institutional power be fully measurable.

\section{REFERENCES}

Anner, M.S. (2011) Solidarity Transformed: Labour Responses to Globalization and Crisis in Latin America. Ithaca, NY: ILR Press.

Aschoff, N.M. (2012) A Tale of Two Crises: Labour, Capital and Restructuring in the US Auto Industry. Socialist Register, 48: 125-148.

Bronfenbrenner, K. and R. Hickey (2004) Changing to Organize. A National Assessment of Union Strategies. In Rebuilding Labor. Organizing and Organizers in the New Union Movement, edited by R. Milkman and K. Voss. Ithaca, NY: Cornell University Press. 
Brookes, M. (2013) Varieties of Power in Transnational Labor Alliances: An Analysis of Workers' Structural, Institutional and Coalitional Power in the Global Economy. Labor Studies Journal, 38(3): 181-200.

Brookes, M. (2015) Power, Labour and Globalization. How Context-appropriate Strategies Help Transnational Labour Alliances Succeed. In Labour and Transnational Action in Times of Crisis, edited by A. Bieler, R. Erne, D. Golden, I. Helle, K. Kjeldstadli, T. Matos and S. Stan. London and New York: Rowman \& Littlefield International.

Brookes, M. (2017) Explaining Employer Responses to Transnational Labor Activism: ndonesia and Cambodia Compared. Comparative Political Studies, 51(6): 699-729. http://journals.sagepub.com/ doi/abs/10.1177/0010414017710266 (accessed 30 November 2017).

Brooks, C. (2016) Organizing Volkswagen: A Critical Assessment. Working USA, 19(3): 395-417.

Capizola, J. (2014) Union-booting Nikki Haley doesn't wear heels for a fashion statement. Birpac Review, 24 February 2014. http://www.bizpacreview.com/2014/02/24/union-booting-nikki-haley-doesnt-wearheels-for-a-fashion-statement-102894 (accessed 10 May 2018).

DaimlerChrysler AG, DC World Employee Committee and International Metalworkers' Federation (IMF) (2002) Social Responsibility Principles of DaimlerChrysler. http://www.imfmetal.org/files/DC\%20code \%20in\%20English.pdf (accessed 10 May 2010).

Elk, M. (2014) After Historic UAW Defeat at Tennessee Volkswagen Plant, Theories Abound. Working In These Times, 15 February 2014. http://inthesetimes.com/working/entry/16300/after uaw defeat at volkswagen in tennessee theories abound (accessed 18 April 2014).

Fairbrother, P., M.A. Hennebert and C. Lévesque (eds.) (2013) Transnational Trade Unionism. Building Union Power. New York: Routledge.

Fichter, M. (1997) Unions in the New Länder: Evidence for the Urgency of Reform. In Negotiating the New Germany: Can Social Partnership Survive? edited by L. Turner. Ithaca, NY: ILR Press.

Fichter, M. and J.K. McCallum (2015) Implementing Global Framework Agreements: The Limits of Social Partnership. Global Networks, 15(1): S65-S85.

Fichter, M. and H. Mund (2015) Transnationale Gewerkschaftsarbeit entlang globaler Wertschöpfungsketten. In Wissenschaft und Arbeitswelt - eine Kooperation im Wandel, edited by L. Pries, H.J. Urban and M. Wannöffel. Baden-Baden: Nomos Edition Sigma.

Fichter, M., D. Stevis and M. Helfen (2012) Bargaining for Corporate Responsibility. The Global and the Local of Framework Agreements in the USA. Business and Politics: 4(3): 1-31.

Friedrich Ebert Stiftung (FES) (2017) Trade Unions in Transformation. https://www.fes.de/lnk/transform (accessed 22 September 2017).

Greven, T. (2016) Die Transnationalisierung des gewerkschaftlichen Organisationslernens. In Globalisierung analysieeren, kritisieren und verändeern, edited by U. Brand, H. Schwenken and J. Wullweber. Hamburg: VSA Verlag.

Grossfield, J. (2011) A New Union Contract. American Prospect. http://prospect.org/article/new-unioncontract (accessed 10 November 2016).

IG Metall (2011) Respektiert Arbeitnehmerrechte. Interview mit Bob King, 1 February 2011. https://www.igmetall.de/interview-mit-bob-king-vorsitzender-der-amerikanischen-6877.htm (accessed 17 October 2016).

IG Metall (2015) IG Metall vertieft Partnerschaft mit US-Gewerkschaft, 20 November 2015. https://www.igmetall.de/partnerschaft-ig-metall-und-uaw-17834.htm (accessed 18 November 2016).

IndustriALL (2010) Strengthening Global Trade Union Work in the Auto Sector. http://www.industriallunion-org/archive/imf/strengthening-global-trade-union-work-in-the-the-auto-sector (accessed 24 
November 2016).

King, B. (2010) A UAW for the $21^{\text {st }}$ Century. Speech delivered to the Center for Automotive Research Conference, Traverse City, Michigan, 2 August 2010.

Lévesque, C. and G. Murray (2010a) Trade Union Cross-border Alliances within MNCs: Disentangling Union Dynamics at the Local, National and International Levels. Industrial Relations Journal, 41(4): 312-32.

Lévesque, C. and G. Murray (2010b) Understanding Union Power: Resources and Capabilities for Renewing Union Capacity. Transfer: European Review of Labour and Research, 16(3): 333-50.

Liebman, W. (2016) US Trade Unions and German Subsidiaries. Soziales Recht, 6(4): 143-57.

Logan, J. (2006) The Union Avoidance Industry in the United States. British Journal of Industrial Relations, 44(4): 651-75.

Logue, J. (1980) Toward a Theory of Trade Union Internationalism. Gothenburg: University of Gothenburg Press.

McCallum, J.K. (2013) Global Unions, Local Power: The New Spirit of Transnational Labor Organizing. Ithaca, NY: ILR Press.

Newsome, J., J. Bair and A. Rainnie (eds.) (2015) Putting Labour in its Place: Labour Process Analysis and Global Value Chains. London: Palgrave.

Niforou, C. (2015) Labour Leverage in Global Value Chains: The Role of Interdependencies and Multi-level Dynamics. Journal of Business Ethics, 130(2): 301-11.

Rubinstein, S.A. (2000) The Impact of Co-management on Quality Performance: The Case of the Saturn Corporation. Industrial \& Labour Relations Review, 53(2): 197-218.

Rubinstein, S.A. and T.A. Kochan (2001) Learning from Saturn. Possibilities for Corporate Governance and Employee Relations. Ithaca, NY: ILR Press.

Ruckelshaus, C. and S. Leberstein (2014) Manufacturing Low Pay: Declining Wages in the Jobs that Built America's Middle Class. New York: National Employment Law Project.

Silvia, S.J. (2013) Holding the Shop Together. German Industrial Relations in the Postwar Era. Ithaca, NY: Cornell University Press.

Silvia, S.J. (2017) The United Auto Workers' Attempt to Unionize Volkswagen Chattanooga. ILR Review, 71(3): 600-24.

Thomas, J. (2011) Bob King: If UAW can't organize foreign plants, “I don’t think there's a long-term future for the union". Crain's Detroit Business, 18 January 2011. http://www.crainsdetroit.com/article/20110118/FREE/110119848/bob-king-if-uaw-cant-organizeforeign-plants-i-dont-think (accessed 4 November 2016).

Turner, L. (1991) Democracy at Work. Changing World Markets and the Future of Labor Unions. Ithaca, NY: Cornell University Press.

United Automobile Workers (UAW) (2011) Principles for Fair Union Elections. Detroit, MI: UAW.

United Automobile Workers (UAW) (2015a) New Models of Employee Representation to the Explored. Solidarity Magarine, 7 December 2015. https://uaw.org/solidarity-magazine/uaw-igmetall-partnership-launch-joint-project (accessed 18 November 2016).

United Automobile Workers (UAW) (2015b) Press Release, 19 November 2015. http://uaw.org/uaw-ig-metall-announce-u-s-partnership (accessed 22 November 2015). 
Volkswagen AG, Volkswagen Group Global Works Council and International Metalworkers' Federation (2002) Declaration on Social Rights and Industrial Relationships at Volkswagen. Wolfsburg, Germany: Volkswagen AG.

Volkswagen AG, Volkswagen Group Global Works Council and International Metalworkers' Federation (2009) Charter on Labour Relations within the Volkswagen Group. Bratislava: Volkswagen AG.

Wetzel, D. (ed.) (2013) Organizing. Die Veränderung der gewerkschaftlichen Praxis durch das Prinzip Beteiligung. Hamburg: VSA Verlag.

\section{ACRONYMS}

BMW Bayerische Motorenwerke

CWA Communication Workers of America

DC DaimlerChrysler

DGB German Trade Union Federation (Deutscher Gewerkschaftsbund)

GM General Motors Corporation

IMF International Metalworkers' Federation

TLI Transatlantic Labour Institute

TPI Transnational Partnership Initiative

UAW United Automobile, Aerospace and Agricultural Implement Workers of America

VW Volkswagen

\section{ACKNOWLEDGEMENTS}

I would like to express my thanks to the project teams from the UAW and the IG Metall for their cooperation. I am also grateful for the support and encouragement of the project team of "Trade Unions in Transformation", and especially the editors of this Special Issue. Last, but certainly not least, I have benefitted greatly from the very constructive input given by two anonymous reviewers.

\section{BIOGRAPHICAL NOTE}

MiCHAEL FiCHTER, born and raised in the United States, completed his $\mathrm{PhD}$ in political science at the Freie Universität Berlin, where he specialised in German and European labour relations until his retirement in 2011. From 2005 to 2012 he taught courses on transnational corporations and global labour relations at the Global Labour University in Germany. His more recent research and publications have been on the implementation of Global Framework Agreements and labour relations in global value chains. He is currently involved in the Trade Unions in Transformation project at the Friedrich Ebert Foundation and is a consultant to the joint IG Metall - UAW project presented in this issue. [Email: mike.fichter@global-labour-university.org] 